\title{
Charakterystyka bimetali cyrkon-stal zgrzewanych wybuchowo przy różnych parametrach procesu
}

\section{The characteristic of zirconium-steel bimetalics strips fabricated by explosive welding using different process parameters}

\section{Streszczenie}

W artykule przedstawiono wyniki prób związanych $z$ doborem optymalnych parametrów procesu zgrzewania wybuchowego próbnych płyt z cyrkonu Zr 700 z dwoma gatunkami stali: SA-516 Gr. 70 i 10CrMo9-10. Badania prowadzono dla złączy w stanie wyjściowym, tj. bezpośrednio po zgrzewaniu wybuchowym. Poddano analizie zmiany strukturalne łączonych blach, ze szczególnym uwzględnieniem charakterystyki granicy połączenia. Wykonano badania właściwości mechanicznych otrzymanych platerów, tj. próbę ścinania, odrywania oraz zginania bocznego. Systematyczne pomiary rozkładu mikrotwardości pozwoliły na analizę zjawiska umocnienia materiału w wyniku procesu zgrzewania wybuchowego, zarówno w strefie bezpośrednio przy granicy połączenia, jak również w całym przekroju plateru. Analiza uzyskanych wyników pozwoliła na ocenę wpływu parametrów procesu zgrzewania wybuchowego na jakość uzyskanego połączenia, tj. jego charakterystykę oraz właściwości wytrzymałościowe. Stwierdzono, że optymalne właściwości można uzyskać przy najniższych z zastosowanych parametrów procesu.

\section{Wstęp}

W okresie wzrostu wydajności produkcji i konkurencyjności producenci muszą zwracać szczególną uwagę na konieczność poprawy jakości oraz trwałości wytwarzanych wyrobów, co jest to związane z poszukiwaniem i stosowaniem materiałów o coraz lepszych

Dr Mariusz Prażmowski - Politechnika Opolska, prof. dr hab. inż. Henryk Paul - Instytut Metalurgii i Inżynierii Materiałowej PAN, Kraków.

\section{Abstract}

The paper presents the results of trials aimed at selecting optimal parameters of the explosion welding process for test zirconium plates with two grades of steel - SA- $516 \mathrm{Gr} 70$ and 10CrMo9-10. The research was carried out for as-bonded welds, i.e. immediately following explosion welding. Structural changes of the joined sheets underwent analysis, particularly focusing on the characteristic of the bond boundary. Mechanical properties of the clads were tested by shearing, peel test and lateral bending. Systematic measurements of microhardness enabled analysing the strengthening of the material at the bond zone and throughout the whole section of the clad. The analysis make possible the description of the process parameters influence on the quality of the bond, i.e. its morphology and strength properties. It was concluded that the optimal properties of the clad can be achieved with the lowest values of the process parameters. właściwościach. Szczególnie przemysł chemiczny i energetyczny wykazuje zapotrzebowanie na takie materiały, które zapewnią jednocześnie odporność na działanie agresywnych środowisk w nowoczesnych instalacjach. Do tej grupy można zaliczyć metale reaktywne, tj. tytan, niob, tantal, cyrkon oraz ich stopy. Niestety materiały te są drogie, a także w wielu przypadkach ich wytrzymałość może być niewystarczająca do przenoszenia obciążeń wynikających z konstrukcji lub przeznaczenia urządzenia. Jednym z rozwiązań umożliwiających połączenie wysokiej wytrzymałości, dobrej odporności korozyjnej i niewielkich kosztów wytworzenia jest zastosowanie 
materiałów platerowanych. W tym przypadku wykorzystuje się połączenie tańszego materiału, które można zapewnić wysokie właściwości mechaniczne $z$ materiałem drogim, o dobrych właściwościach ochronnych, przy czym często, cienka warstwa jest wystarczająca, aby znaczenie wydłużyć okres eksploatacji instalacji.

Wiele technologii umożliwia łączenie ze sobą materiałów o zbliżonych właściwościach, np. napawanie, walcowanie pakietowe, zgrzewanie dyfuzyjne itp. Trudniejsze jest połączenie materiałów różniących się w znacznym stopniu właściwościami fizykochemicznymi. Wówczas jedynym możliwym rozwiązaniem pozostaje technologia zgrzewania wybuchowego. Technologia ta jest od wielu lat stosowana w przemyśle do łączenia metali i stopów o silnie zróżnicowanych właściwościach fizycznych i metalurgicznych. Jest przy tym szczególnie przydatna w łączeniu materiałów, dla których tradycyjne techniki spajania nie zapewniają uzyskania platerów o zadowalającej jakości połączenia. Inną znaczącą zaletą tej metody spajania jest to, że proces ten w zasadzie jest wolny od fizycznych, mechanicznych i temperaturowych ograniczeń tradycyjnego procesowi zgrzewania.

Z omawianej grupy materiałów reaktywnych coraz większym zainteresowaniem cieszy się cyrkon, charakteryzujący się wysoką odpornością na korozję w różnych agresywnych środowiskach, tj. zawierających ługi, w roztworach kwasu solnego, azotowego, siarkowego i fosforowego, we wrzącym kwasie mrówkowym, octowym, mlekowym, cytrynowym i chlorooctowym, zwłaszcza przy pracy elementów $w$ temperaturze podwyższonej [3]. Cyrkon (i jego stopy) jest metalem o bardzo niskim współczynniku pochłaniania gorących neutronów, stąd też znajduje zastosowanie w budowie niektórych elementów reaktorów jądrowych. Dodatkowo ma on najwyższy współczynnik odbicia promieniowania elektromagnetycznego, dlatego też (w postaci blach) wykorzystuje się go do osłony pomieszczeń przed promieniowaniem. Niestety wysoki koszt produkcji jest podstawowym ograniczeniem powszechnego zastosowania cyrkonu jako materiału konstrukcyjnego. Możliwość wytwarzania blach platerowanych cyrkonem, z wykorzystaniem technologii zgrzewania wybuchowego, w znacznym stopniu może przyczynić się do stosowania na skalę przemysłową cyrkonu oraz jego stopów. Na jakość oraz wytrzymałość uzyskanego połączenia ma wpływ obszar powstający na granicy zgrzewanych metali. Geometryczna oraz strukturalna budowa połączeń zgrzewanych zależy przede wszystkim od rodzaju zgrzewanych metali, parametrów zgrzewania oraz grubości zgrzewanych elementów [1, 2].
W artykule przedstawiono wyniki badań mechanicznych i strukturalnych strefy złącza płyt próbnych bimetali cyrkon Zr 700 - stal wykonanych technologią zgrzewania wybuchowego, przy różnych parametrach procesu. Materiały te zostały wykonane przez ZTW EXPLOMET w ramach pracy badawczej realizowanej przez Politechnikę Opolską.

\section{Metodyka badań}

Przedmiotem analizy są układy bimetalowe wykonane technologią zgrzewania wybuchowego przy różnych parametrach procesu, tj. prędkości detonacji ( $v$ ) oraz odległości pomiędzy blachami (h). Materiał do badań wykonano na poligonie, stosując układ dwóch płyt równoległych według schematu przedstawionego na rysunku 1. Do wykonania układów próbnych wykorzystano płyty o wymiarach $300 \times 500 \mathrm{~mm}$. Materiałem nakładanym we wszystkich przypadkach była blacha cyrkonowa Zr 700 (nazwa handlowa Zircadyne) o grubości 3,175 mm. Jako materiał podstawowy zastosowano dwa rodzaje blach stalowych, w budowie aparatury przemysłowej: SA-516 Gr.70 o grubości wyj-
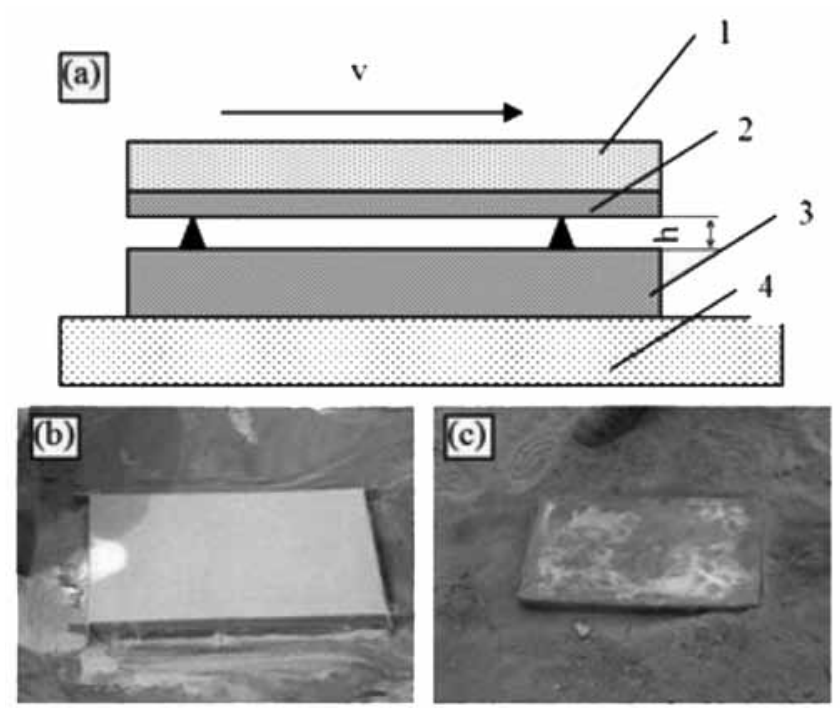

Rys. 1. Układy próbne bimetalu Zr-stal: a) schemat układu, 1 - materiał wybuchowy, 2 - płyta lotna $\operatorname{Zr} 700,3$ - płyta bazowa stal, 4 - podłoże, $v$ - prędkość detonacji, $\mathrm{h}$ - odległość płyt; b) układ przed strzałem, c) bimetal po wykonaniu połączenia

Fig. 1. Trial structures of bi-metal $Z r$ - carbon steel: a) schematic illustration of the explosive cladding set-up: 1 - explosive, $2-\mathrm{Zr} 700$ flyer plate, 3 - P265GH steel base plate, 4 - substrate, $v$ - detonation velocity, $\mathrm{h}-$ distance between plates, $\mathrm{b}$ ) before the explosion, c) the bi-metal after bonding

Tablica I. Skład chemiczny łączonych blach, wg atestu dostawcy

Table I. The chemical composition of joined metal sheets, as per the supplier's certificate

\begin{tabular}{|c|c|c|c|c|c|c|c|c|c|c|c|}
\hline \multirow{2}{*}{ Materiał } & \multicolumn{11}{|c|}{ Skład chemiczny, \% } \\
\hline & \multicolumn{2}{|c|}{ C } & \multicolumn{2}{|c|}{$\mathrm{FeCr}$} & \multicolumn{2}{|c|}{\begin{tabular}{l|l}
$\mathrm{H}$ & \\
\end{tabular}} & \multirow{2}{*}{$\begin{array}{c}\mathrm{O} \\
0,05\end{array}$} & \multicolumn{2}{|c|}{$\mathrm{Zr}+\mathrm{Hf}$} & \multicolumn{2}{|c|}{$\mathrm{N}$} \\
\hline $\mathrm{Zr} 700$ & \multicolumn{2}{|c|}{$<0,002$} & \multicolumn{2}{|c|}{0,05} & \multicolumn{2}{|c|}{$<0,0003$} & & \multicolumn{2}{|c|}{$>99,2$} & \multicolumn{2}{|c|}{$<0,002$} \\
\hline & $\mathrm{C}$ & $\mathrm{Mn}$ & $\mathrm{Si}$ & $\mathrm{P}$ & $\mathrm{S}$ & $\mathrm{Ni}$ & $\mathrm{Cr}$ & Mo & $\mathrm{Al}$ & $\mathrm{N}$ & $\mathrm{Nb}$ \\
\hline SA516 Gr. 70 & 0,170 & 1,13 & 0,345 & 0,008 & 0,001 & 0,285 & 0,150 & 0,035 & 0,045 & 0,004 & 0,019 \\
\hline 10CrMo9-10 & 0,123 & 0,500 & 0,230 & 0,012 & 0,005 & 0,030 & 2,130 & 0,947 & 0,036 & 0,006 & 0,005 \\
\hline
\end{tabular}


ściowej $20 \mathrm{~mm}$ oraz 10CrMo 9-10 o grubości $18 \mathrm{~mm}$. Skład chemiczny stosowanych metali przedstawiono w tablicy I.

W celu ustalenia optymalnych parametrów platerowania zgrzewanie realizowano, zmieniając dwa podstawowe parametry procesu - początkową odległość pomiędzy powierzchniami płyty podstawowej i nastrzeliwanej (h), i prędkość detonacji (v). Takie podejście umożliwiło otrzymanie dla poszczególnych układów materiałów złączy o różnej charakterystyce. Oznaczenie płyt próbnych z ich zależnością pomiędzy parametrami procesu zestawiono $w$ tablicy II. Podczas detonacji we wszystkich przypadkach mierzona była prędkość (v). W tym celu na gotowych układach strzałowych zamontowane zostały przewody światłowodowe $z$ urządzeniem pomiarowym Explomet. Różne prędkości detonacji uzyskano dzięki zastosowaniu ładunków o zróżnicowanych parametrach materiału wybuchowego.

Wszystkie płyty próbne (po zgrzaniu) poddano dwuetapowym badaniom ultradźwiękowym na całej po-

Tablica II. Oznaczenie wytworzonych płyt oraz zależności pomiędzy parametrami procesu

Table II. Designation of the produced plates and the relations between process parameters

\begin{tabular}{|l|c|c|c|c|c|c|}
\hline \multirow{2}{*}{$\begin{array}{c}\text { Parametru } \\
\text { procesu }\end{array}$} & \multicolumn{5}{|c|}{$\begin{array}{c}\text { Materiał nakładany + podstawowy } \\
(3,175 \mathrm{~mm}+18 \mathrm{~mm})\end{array}$} & $\begin{array}{c}\mathrm{Zr} 700+\mathrm{SA} 516 \mathrm{Gr} \text {. 70 } \\
(3,175 \mathrm{~mm}+20 \mathrm{~mm})\end{array}$ \\
\hline Płyta & $\mathrm{A} 6$ & $\mathrm{~A} 7$ & $\mathrm{~A} 10$ & $\mathrm{~A} 8$ & $\mathrm{~A} 9$ & $\mathrm{~A} 11$ \\
\hline $\begin{array}{l}\text { Prędkość } \\
\text { detonacji } \mathrm{v}, \mathrm{m} / \mathrm{s}\end{array}$ & $1,1 \mathrm{v}_{1}$ & $\mathrm{v}_{1}$ & $1,25 \mathrm{v}_{1}$ & $1,1 \mathrm{v}_{1}$ & $1,1 \mathrm{v}_{1}$ & $1,4 \mathrm{v}_{1}$ \\
\hline $\begin{array}{l}\text { Odległość płyt } \\
\mathrm{h}, \mathrm{mm}\end{array}$ & $\mathrm{h}_{1}$ & $\mathrm{~h}_{1}$ & $3 \mathrm{~h}_{1}$ & $2 \mathrm{~h}_{1}$ & $3 \mathrm{~h}_{1}$ & $2 \mathrm{~h}_{1}$ \\
\hline
\end{tabular}

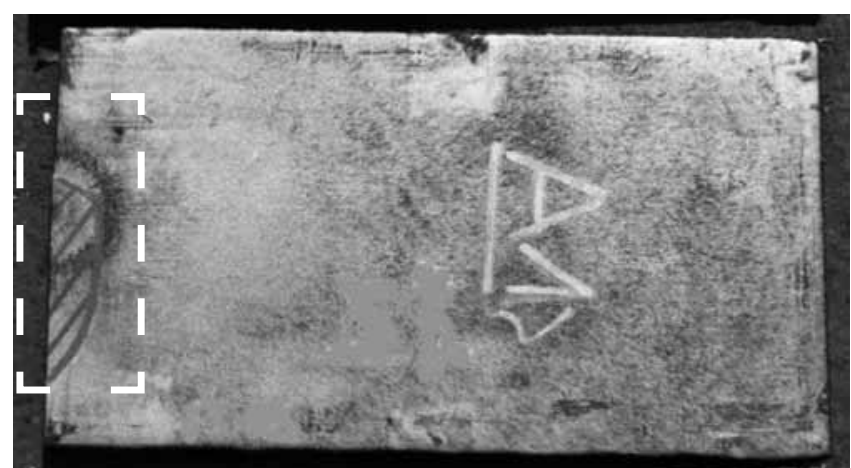

Rys. 2. Płyta próbna z zaznaczonym obszarem nieciągłości miejsca pobudzenia

Fig. 2. Test plate with the discontinuity area marked around the activation point

wierzchni w celu określenia spójności połączenia i ciągłości złącza. Pierwszy etap realizowano bezpośrednio po zgrzaniu, natomiast drugi po prostowaniu na prasie. Dla wszystkich płyt prezentowanych w artykule wynik był pozytywny $w$ odniesieniu do obszaru połączenia. Przykładową płytę próbną z zaznaczonym obszarem po badaniach ultradźwiękowych przedstawiono na rysunku 2.

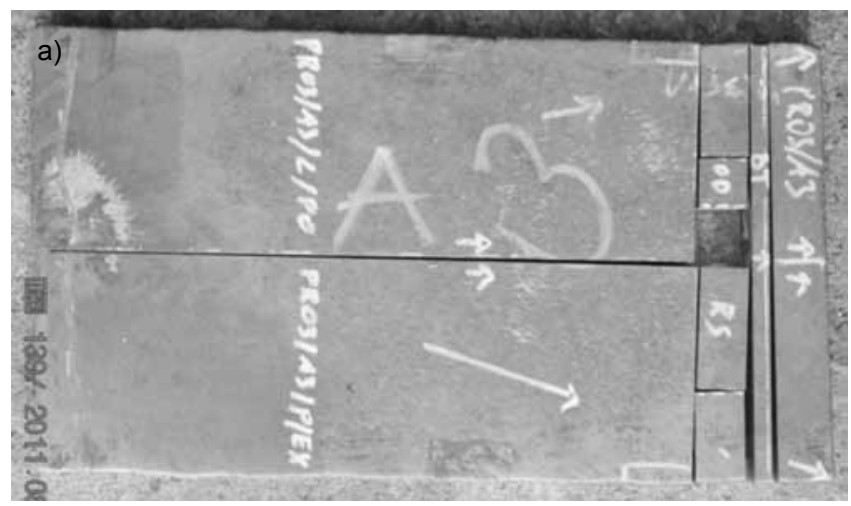

b)

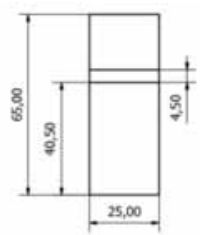

d)

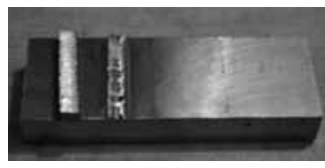

f)

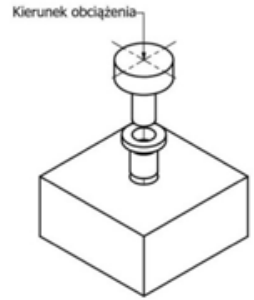

c)

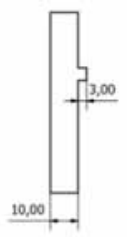

e)
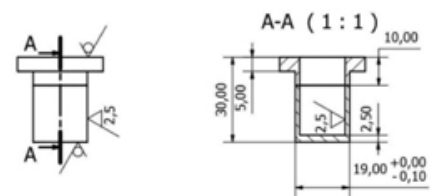

g)

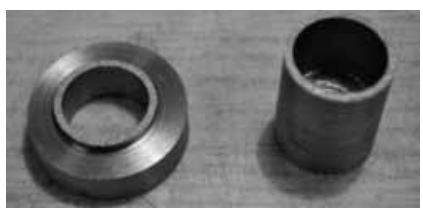

Rys. 3. Badania mechaniczne bimetalu Zr-stal: a) miejsce pobrania próbek, b) próbka do próby ścinania, c) schemat próby ścinania, d) próbka po próbie ścinania, e) próbka do próby odrywania, f) schemat próby odrywania, g) próbka po próbie odrywania

Fig. 3. Mechanical tests of Zr-steel bimetal: a) sampling spot, b) shearing test sample, c) shear test diagram, d) post-shear sample view, e) peel test sample, f) peel test diagram, g) the view of the sample after the peel test

Tablica III. Wyniki badań mechanicznych

Table III. Mechanical test results

\begin{tabular}{|c|c|c|c|c|c|c|c|c|}
\hline \multirow{2}{*}{\multicolumn{2}{|c|}{ Parametry procesu }} & \multicolumn{7}{|c|}{ Materiał nakładany + podstawowy } \\
\hline & & \multicolumn{4}{|c|}{ Zr $700+10$ CrMo9-10 $(3,175 \mathrm{~mm}+18 \mathrm{~mm})$} & \multicolumn{3}{|c|}{$\mathrm{Zr} 700+\mathrm{SA} 516 \mathrm{Gr} .70(3,175 \mathrm{~mm}+20 \mathrm{~mm})$} \\
\hline \multicolumn{2}{|l|}{ Płyta } & A4 & A6 & A7 & A10 & A8 & A9 & A11 \\
\hline \multirow{2}{*}{$\begin{array}{l}\text { Wytrzymałość na } \\
\text { ścinanie } R_{\mathrm{s}}\end{array}$} & $\mathrm{MPa}$ & 376 & 321 & 407 & 335 & 351 & 353 & 389 \\
\hline & miejsce & $\mathrm{Zr}$ & $\mathrm{Zr}$ & $\mathrm{Zr}$ & G & $\mathrm{Zr}$ & $\mathrm{Zr}$ & G \\
\hline \multirow{2}{*}{$\begin{array}{l}\text { Wytrzymałość na } \\
\text { odrywanie } \mathrm{R}_{\mathrm{o}}\end{array}$} & $\mathrm{MPa}$ & 533 & 409 & 486 & 61 & 449 & 475 & 144 \\
\hline & miejsce & G & $\mathrm{Zr}$ & $\mathrm{Zr}$ & G & $\mathrm{Zr}$ & $\mathrm{Zr}$ & G \\
\hline
\end{tabular}




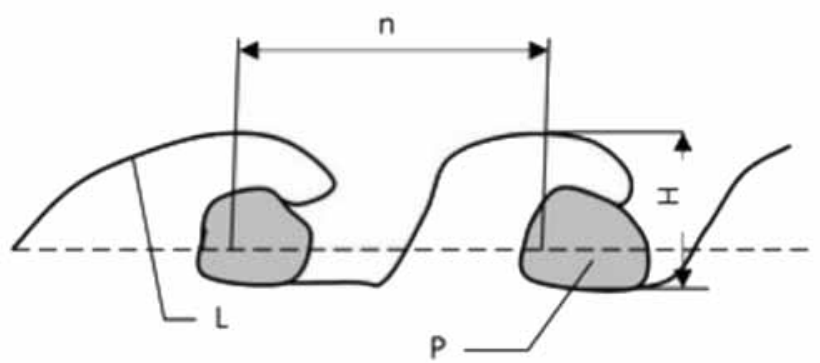

Rys. 4. Podstawowe parametry złącza: $H$ - wysokość fali, $L-d ł u-$ gość linii złącza, $n$ - długość fali, $P$ - pole powierzchni przetopień Fig. 4. Basic bond parameters: $\mathrm{H}$ - wave height, $\mathrm{L}-$ length of the bond line, $n$ - wave length, $P$ - fusion surface area

Dla wszystkich układów próbnych przeprowadzono badania właściwości mechanicznych wymaganych dla materiałów platerowanych wybuchowo wg EN 13445-2, tj. próbę gięcia bocznego, próbę ścinania oraz próbę odrywania (rys. 3). Do badań pobrano próbki ze wszystkich platerów. Wyniki testów podano w tablicy III.

We wszystkich próbach zginania bocznego próbki zostały zgięte o kąt $180^{\circ}$, nie wykazując żadnych wad w postaci pęknięć lub rozwarstwień.

Z wykonanych platerów przygotowano materiał do badań strukturalnych. Zgłady metalograficzne wykonano na powierzchniach równoległych do kierunku przemieszczania się fali (i jednocześnie prostopadłych do powierzchni łączenia). W pierwszym etapie powierzchnie próbek przygotowywano mechanicznie przez szlifowanie na papierach ściernych o zmieniającej się gradacji, a następnie polerowano $z$ użyciem past diamentowych. Kolejnym etapem było polerowanie i trawienie na polerce elektrolitycznej LectroPol 5 z zastosowaniem elektrolitu A3 firmy Struers ${ }^{\mathrm{TM}}$. Tak przygotowane zgłady poddano obserwacjom na mikroskopie świetInym Olympus IX70, na podstawie których analizowano zmiany strukturalne oraz wykonano makroanalizy granicy połączenia. Posłużyły one do opracowania ogólnej charakterystyki złącza oraz ilościowego ujęcia udziału warstwy przetopień. Dla każdego $z$ analizowanych układów określono podstawowe parametry złącza, tj.: wysokość fali $(H)$, długość linii złącza (L), długość fali (n) i pole powierzchni przetopień $(P)$ (rys. 4).

Z uzyskanych wyników wyznaczono wartości średnie, które posłużyły do określenia, za pomocą równania (1), tzw. równoważnej grubości przetopień (współczynnika RGP), charakteryzującej udział warstwy przetopionej na granicy łączonych bimetali:

$$
R G P=\frac{P}{L} \quad \mu m
$$

gdzie: $P$ - sumaryczne pole powierzchni przetopień, $\mu m^{2} ; \mathrm{L}$ - długość linii złącza, $\mu \mathrm{m}$.

Pomiary mikrotwardości metodą Vickersa przy obciążeniu $10 \mathrm{G}$ przeprowadzono zgodnie z PN-EN ISO 6507-1:2007. Celem pomiarów była obserwacja zmian umocnienia poszczególnych warstw w pobliżu strefy połączenia (do $0,5 \mathrm{~mm}$ od granicy złącza), jak również określenie rozkładu twardości w całym przekroju plateru. Pomiary wykonywano mikrotwardościomierzem LECO MHT Series 200, wzdłuż linii pomiarowych prostopadłych do granicy połączenia (3 serie).

\section{Wyniki badań}

\section{Obserwacje strukturalne}

Dla wszystkich układów próbnych wykonano badania mikrostrukturalne w obszarze złącza. Na rysunku 5 przedstawiono obrazy mikrostruktury obserwowane na mikroskopie świetlnym, gdzie dobrze uwidoczniono formowanie się charakterystycznego złącza falistego, dla szerokiego zakresu zastosowanych parametrów technologicznych spajania. Dla każdego plateru wykonano pomiary charakterystycznych parametrów złącza, wykorzystując oprogramowanie do analizy obrazu. Wyniki pomiaru takich parametrów jak: wysokość fali $\mathrm{H}$, jej długość $n$, jak również długość linii złącza $L$ i sumaryczne pole powierzchni warstwy przetopionej $\mathrm{P}$, przedstawiono w tablicy IV. Na podstawie dwóch ostatnich parametrów wyznaczono współczynnik RGP charakteryzujący udział warstwy przetopionej w złączu.

$\mathrm{Na}$ podstawie analizy mikroskopowej oraz pomiarów parametrów złącza (tabl. IV) wszystkie połączenia można zakwalifikować do grupy połączeń falistych o nieregularnym przebiegu. W przypadku

Tablica IV. Parametry opisujące kształt fali oraz udział warstwy przetopionej w złączu

Table IV. Parameters describing wave shape and the quantity of the fusion zone

\begin{tabular}{|c|c|c|c|c|c|c|}
\hline $\bar{z} \frac{\bar{x}}{\frac{0}{0}}$ & 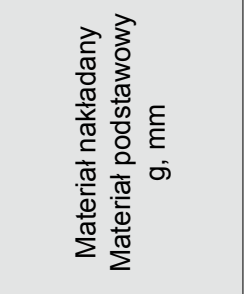 & 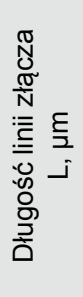 & 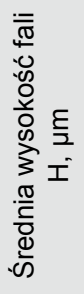 & 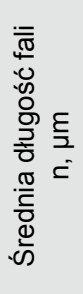 & 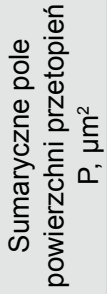 & 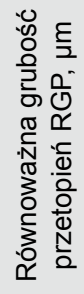 \\
\hline A6 & $\begin{array}{c}\operatorname{Zr} 700(3,17) \\
10 \text { CrMo9-10 (18) }\end{array}$ & 9899 & 31 & 275 & 3523 & 0,36 \\
\hline A7 & $\begin{array}{c}\operatorname{Zr} 700(3,17) \\
10 \text { CrMo9-10 (18) }\end{array}$ & 8523 & 28 & 240 & 3273 & 0,38 \\
\hline A10 & $\begin{array}{c}\operatorname{Zr} 700(3,17) \\
10 C r M o 9-10(18)\end{array}$ & 11506 & 276 & 1418 & 155155 & 13,48 \\
\hline A8 & $\begin{array}{c}\mathrm{Zr} 700(3,17) \\
\text { SA-516 Gr } 70(20)\end{array}$ & 11279 & 54 & 492 & 5148 & 0,46 \\
\hline A9 & $\begin{array}{c}\text { Zr } 700(3,17) \\
\text { SA-516 Gr } 70(20)\end{array}$ & 9709 & 35 & 188 & 9807 & 1,01 \\
\hline A11 & $\begin{array}{c}\mathrm{Zr} 700(3,17) \\
\text { SA-516 Gr } 70(20)\end{array}$ & 13659 & 218 & 977 & 145061 & 10,62 \\
\hline
\end{tabular}



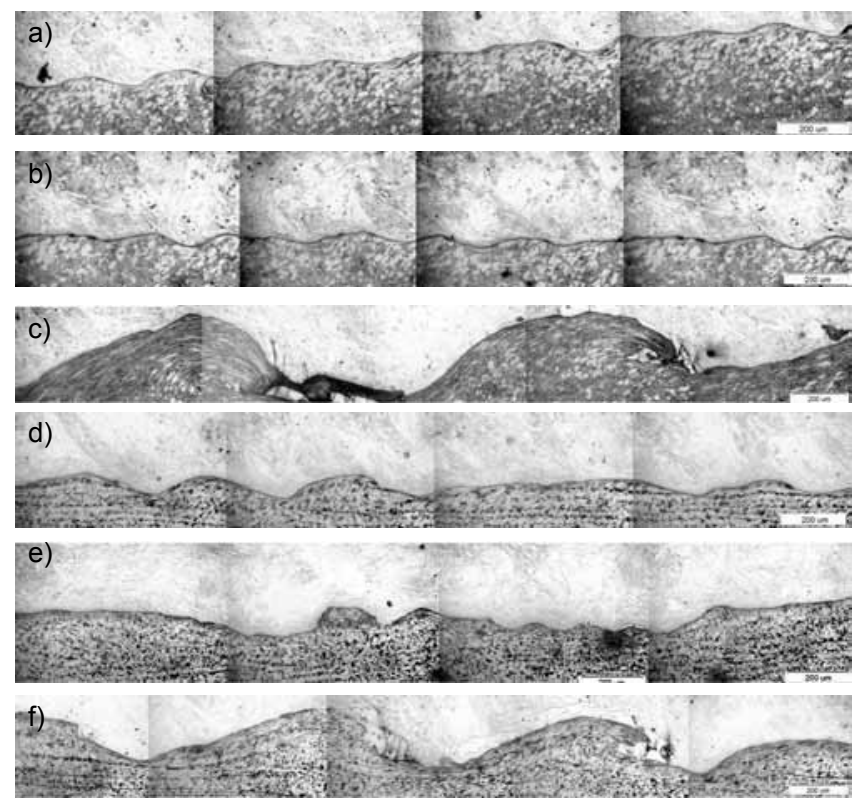

Rys. 5. Charakterystyka strefy złącza $w$ zależności od zastosowanych parametrów wybuchu: a) A6 - $1,1 \mathrm{v}_{1}, \mathrm{~h}_{1}$, b) A7 $-\mathrm{v}_{1}, \mathrm{~h}_{1}$, c) A10 $-1,25 v_{1}, 3 h_{1}$, d) $\left.A 8-1,1 v_{1}, 2 h_{1}, e\right) A 9-1,1 v 1,3 h 1$, f) A11- $1,4 v_{1}$, $2 h_{1}$. Pow 200x

Fig. 5. Characteristics of the bond zone depending on explosion parameters applied: a) A6 $-1,1 v_{1}, h 1$, b) $A 7-v_{1}, h_{1}$, c) A10 - 1,25 $v_{1}$, $3 h_{1}$, d) A8 - 1,1v1, 2h, e) A9 - 1,1 $\mathrm{v}_{1}, 3 \mathrm{~h}_{1}$, f) A11 $-1,4 \mathrm{v}_{1}, 2 \mathrm{~h}_{1}$. Magn. 200x

próbek o niskich parametrach procesu $(A 6, A 7)$ oraz małych prędkościach detonacji i dużych odległościach początkowych (A8, A9) charakterystyka granicy połączenia jest podobna, tj. wysokość fali zawiera się w granicach $28 \div 54 \mu \mathrm{m}$, natomiast jej długość wynosi $188 \div 492 \mu \mathrm{m}$. W trzech przypadkach platery charakteryzowały się taką samą prędkością detonacji, natomiast różną odległoścą początkową pomiędzy blachami (A6, A8, A9). Analizując ten parametr w powiązaniu ze współczynnikiem RGP można zauważyć, że ma on związek z obecnością warstwy przetopionej w strefie złącza. Systematyczny wzrost odległości h, odpowiednio: dla $A 6-h_{1}, A 8-2 h_{1}$ oraz A9 $-3 h_{1}$, powoduje wzrost współczynnika RGP: 0,36 , 0,46 i 1,01 $\mu \mathrm{m}$. Jednak odległość pomiędzy blachami nie jest jedynym czynnikiem decydującym o parametrach złącza oraz ilości występujących obszarów przetopień. Można to stwierdzić na podstawie analizy płyt wykonanych przy porównywalnych odległościach początkowych, lecz największej prędkości detonacji (A10, A11). W tym przypadku udział warstwy przetopionej w złączu gwałtownie wzrasta, o czym świadczy wzrost współczynnika RGP o 1-2 rzędy wielkości w stosunku do pozostałych próbek (tabl. IV). Również maksymalne wartości parametrów zgrzewania powodują tworzenie się $4 \div 5$ - krotnie wyższej oraz $2 \div 3$-krotnie dłuższej fali w stosunku do maksymalnych parametrów fali uzyskanej w przypadku platerów wykonanych przy niskich parametrach procesu (tabl. IV).
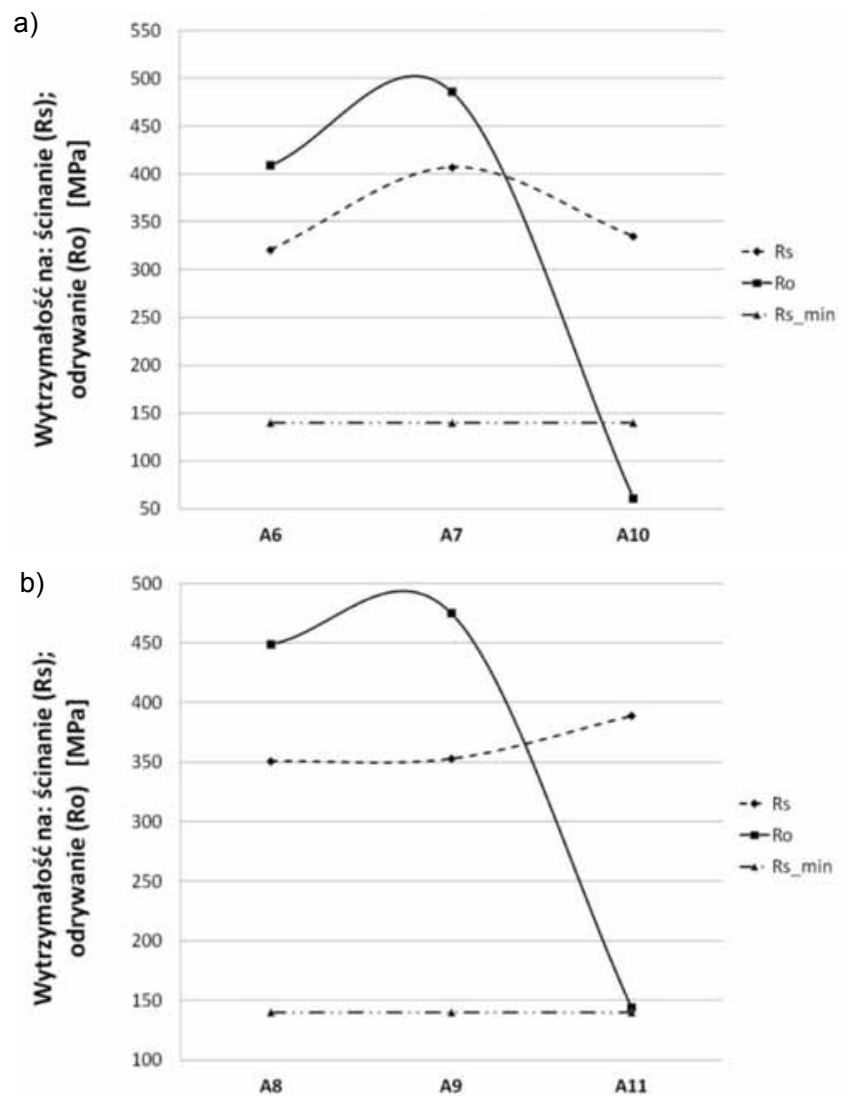

Rys. 6. Właściwości mechaniczne bimetali: a) Zr $700+10 \mathrm{CrMo9-10,}$ b) Zr $700+$ SA 516 Gr.70

Fig. 6. Mechanical properties of bimetals: a) $\mathrm{Zr} 700+10 \mathrm{CrMo9}-10$, b) $\operatorname{Zr} 700+$ SA 516 Gr.70

\section{Badania właściwości mechanicznych}

W celu oceny właściwości mechanicznych połączenia próbki pobrane ze wszystkich platerów poddano próbie ścinania, odrywania i zginania bocznego. Próba ścinania wykazała bardzo dużą wytrzymałość uzyskanych połączeń; wszystkie otrzymane wyniki (tabl. III, rys. 6) ponad dwukrotnie przekraczają przyjętą przez normę wartość minimalną, tj. $\mathrm{R}_{\mathrm{S}}=140 \mathrm{MPa}$. Najwyższą wytrzymałość zarówno na odrywanie $R_{0}=486 \mathrm{MPa}$, jak i na ścinanie $\mathrm{R}_{\mathrm{S}}=407 \mathrm{MPa}$, uzyskano dla bimetalu wytworzonego przy najmniejszych parametrach procesu, tj. odległości pomiędzy blachami i energii wybuchu (A7). Najmniejszą wytrzymałość na ścinanie, $R_{S}=321 \mathrm{MPa}$, wykazał plater (A6) o parametrach zbliżonych do A7, natomiast na odrywanie płyty o najwyższej prędkości i dużych odległościach (A10 i A11). W ich przypadku miejsce ścięcia oraz oderwania zidentyfikowano na granicy połączenia, natomiast w pozostałych w materiale nakładanym (Zr). Przyczyny tak niskiej wytrzymałości na odrywanie w przypadku platerów o najwyższych parametrach (A10 i A11) są związane $z$ dużym udziałem warstwy przetopionej, która jest twarda i krucha, co osłabia właściwości złącza (tabl. IV). Pozostałe próbki uległy zniszczeniu przy 
wysokiej wytrzymałości złącza (tabl. III). We wszystkich przeprowadzonych próbach zginania bocznego, przy zgięciu próbek o kąt $180^{\circ}$ nie stwierdzono oznak pęknięcia lub rozwarstwienia.

\section{Pomiary mikrotwardości}

$\mathrm{Na}$ płytach próbnych wykonano pomiary mikrotwardości w dwóch wariantach. Celem pierwszego była charakterystyka zmian twardości w całym przekroju bimetali. Wyniki tych pomiarów przedstawiono na rysunkach $7 \mathrm{a}$ i $7 \mathrm{~b}$. Na podstawie analizy otrzymanych wyników można stwierdzić, że zmiany twardości wystąpiły na całym przekroju badanych materiałów, zarówno w materiale podstawowym, jak i nakładanym. W drugim wariancie pomiar mikrotwardości obejmował strefę bezpośrednio przy granicy połączenia (rys. 7b i 7c). W tym przypadku największe umocnienie, do ok. 310 HV0,01, można zaobserwować w materiale podstawowym, w odległości $0,15 \mathrm{~mm}$ od granicy połączenia, w układach wykonanych największą energią wybuchu oraz największych odległościach początkowych (A11 i A10). W przypadku układu Zr+SA-516 Gr.70 płyta wykonana przy maksymalnych parametrach (A11) wykazuje ok. $30 \%$ wzrost umocnienia na granicy połączenia w stosunku do dwóch pozostałych układów. W przypadku układu $\mathrm{Zr+10CrMo9-10} \mathrm{wzrost} \mathrm{umoc-}$ nienia dla materiału o najwyższych parametrach zgrzewania (A10), w stosunku do próbek wykonanych przy najniższych parametrach (A6, A7), nie jest tak zauważalny. Można wtedy zaobserwować proporcjonalny wzrost umocnienia dla poszczególnych układów, tj. ok. 260 HV (A6), 280 HV (A7) i 310 HV (A10). Dla tych układów, po stronie materiału nakładanego bezpośrednio przy granicy połączenia, uzyskano umocnienie na jednakowym poziomie ok. 210 HV. Wyraźne zmiany w umocnieniu rozpatrywanych układów można zaobserwować w strefie ok. 0,35 mm od granicy połączenia.

Tak dużą różnicę w umocnieniu płyty podstawowej dla bimetali oznaczonych A10 i A11 można upatrywać w tym, że miały one największą prędkość detonacji (próbka A11 ok. 40\% większą od założonej prędkości początkowej $\mathrm{v}_{1}$, natomiast $\mathrm{A} 10$ o ok. 25\%).
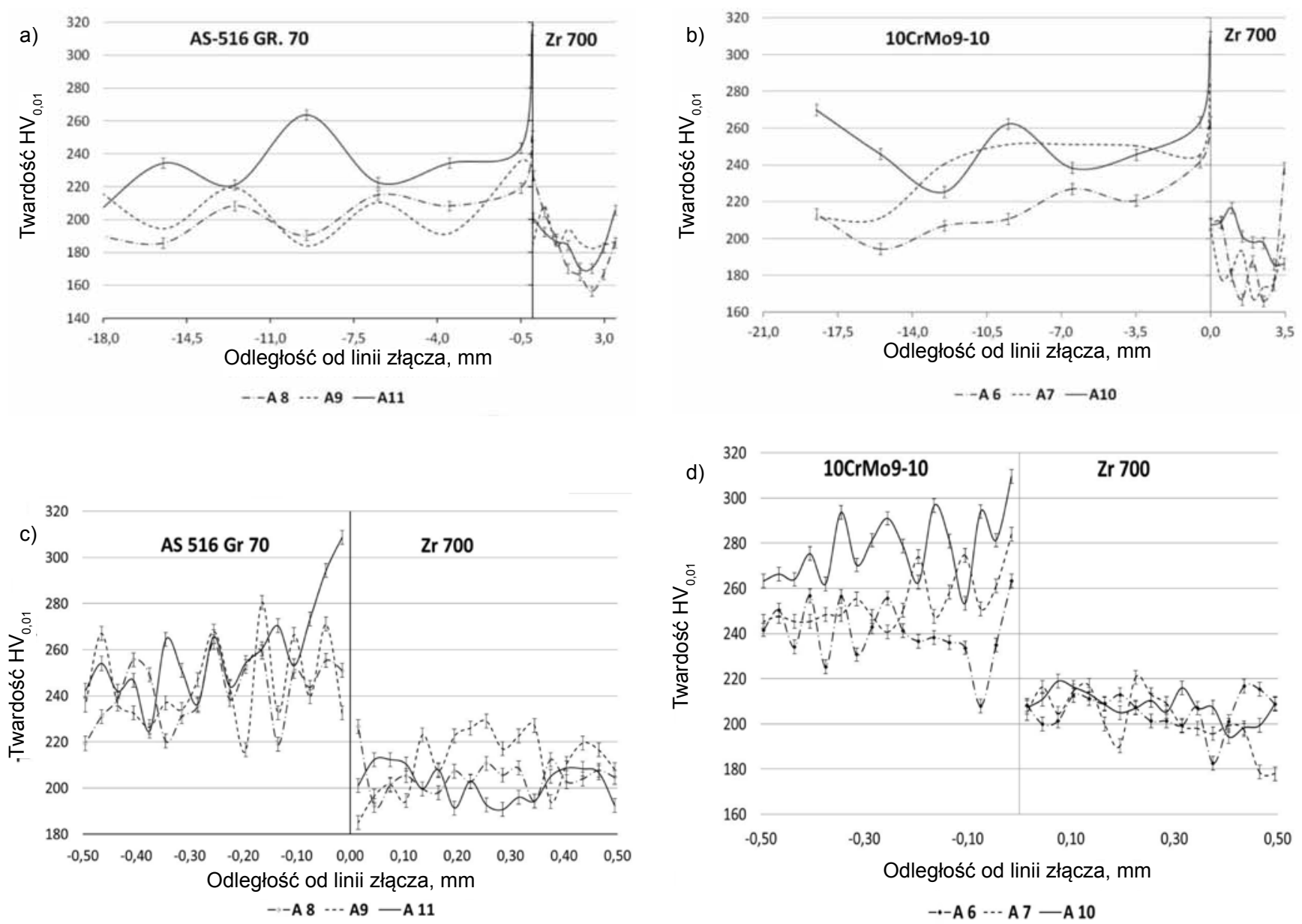

Rys. 7. Rozkład mikrotwardości wzdłuż 3 linii prowadzonych przez platery: a) Zr $700+$ SA 516 Gr.70, b) Zr 700 + 10CrMo9-10 - przez cały przekrój materiału i w strefie połączenia (0,5 mm od granicy złącza): c) Zr $700+\mathrm{SA} 516 \mathrm{Gr} .70$, d) Zr 700 + 10CrMo9-10. Obciążenie $10 \mathrm{G}$

Fig. 7. Microhardness distribution along 3 lines running through the clads: a) Zr $700+$ SA 516 Gr.70, b) Zr $700+10 \mathrm{CrMo9}-10$ throughout the whole section of the material and: c) $\mathrm{Zr} 700+\mathrm{SA} 516 \mathrm{Gr} .70$, d) $\mathrm{Zr} 700+10 \mathrm{CrMo9}-10-$ microhardness distribution in the bond zone $(0.5 \mathrm{~mm}$ from the bond boundary). Load $10 \mathrm{G}$ 


\section{Wnioski}

W pracy poddano analizie strukturę strefy połączenia oraz właściwości bimetali Zr700+SA-516 Gr. 70 oraz Zr700+10CrMo9-10 wykonanych technologią zgrzewania wybuchowego, przy zmiennych parametrach procesu, tj. prędkości detonacji oraz początkowej odległości blach. Przeprowadzone badania pozwalają na sformułowanie następujących wniosków:

- We wszystkich przypadkach otrzymano platery o falistej granicy połączenia i zróżnicowanych parametrach fali.

- Mała odległość początkowa pomiędzy płytami oraz małe prędkości detonacji sprzyjały tworzeniu się połączenia o fali płaskiej, lecz o najlepszych właściwościach wytrzymałościowych, tj. wytrzymałości na ścinanie oraz odrywanie. Duże prędkości detonacji sprzyjały tworzeniu się fali o wysokich parametrach, tj. wysokości oraz długości, jednak wyraźnie wzrastał udział twardej i kruchej warstwy przetopionej w obszarze połączenia. Wpływało to na gwałtowny spadek wytrzymałości na odrywanie.
- W przypadku wszystkich wykonanych platerów zaobserwowano umocnienie zarówno w materiale nakładanym, jak i podstawowym. Największa zmiana twardości występowała w odległości ok. 0,35 mm od strefy połączenia, przy czym większe umocnienie obserwuje się w materiale podstawowym. Umocnienie materiału jest silnie uzależnione od parametrów procesu. Zarówno zwiększenie odległości początkowej, jak i prędkości detonacji powoduje wzrost twardości w strefie połączenia.

- W przypadku rozpatrywanych układów platery o optymalnej charakterystyce granicy połączenia i odpowiednio wysokich właściwościach wytrzymałościowych otrzymano przy niskich wartościach prędkości detonacji oraz średnich i niskich odległościach początkowych pomiędzy łączonymi blachami.

\section{Literatura}

[1] Walczak W.: Zgrzewanie wybuchowe metali i jego zastosowanie, Warszawa 1989, WNT.

[2] Dyja H., Maranda A., Trębiński R.: Technologie wybuchowe w inżynierii materiałowej, Częstochowa 2001, Wydawnictwo Wydziału Metalurgii i Inżynierii Materiałowej Politechniki Częstochowskiej.

[3] Tubielewicz K., Błaszczuk W., Melechow R.: Technologiczne właściwości cyrkonu, Wydawnictwo Politechniki Częstochowskiej, 2001.

[4] Prażmowski M., Paul H., Bański R.: Wpływ wybranych parametrów zgrzewania wybuchowego na właściwości oraz strukturę bimetalu cyrkon - stal węglowa. Rudy i metale nieżelazne, R. 56/2011 s. 697-703.

[5] Paul H., Faryna M., Prażmowski M., Bański R.: Changes in the bonding zone of explosively welded sheets, Archives of Metalurgy and Materials, Vol. 56, 2011, s. 443-474.

[6] Paul H., Miszczyk M., Prażmowski M., Szulc Z.: Analiza zmian w warstwie połączenia płyt Al/Cu spajanych wybuchowo, Inżynieria Materiałowa 5/2010, s. 1339-1346.

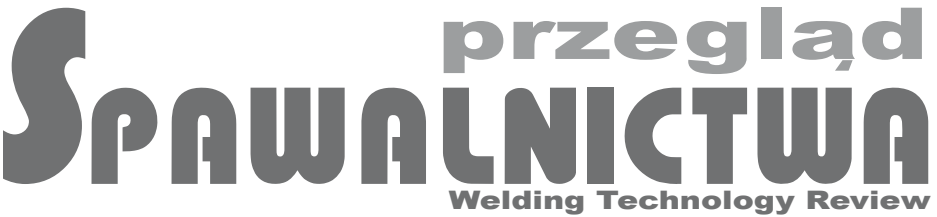

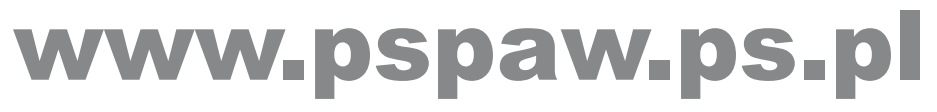

